\title{
The Reputation of Louis XV's Vice-Admirals of France
}

\author{
Simon Surreaux
}

Centre Roland Mousnier

The kingdom of France had only two admirals during the eighteenth century: the Comte de Toulouse (1678-1737) and his son, the Duke of Penthièvre (172593). The former was the illegitimate son of Louis XIV and the Marchioness of Montespan. ${ }^{39}$ The Earl of Toulouse took part in only one military campaign, in 1704. During this campaign he was present at the Battle of Vélez-Málaga (24 August 1704), with the Vice-Admiral d'Estrées (1660-1737), fought against the British fleet, commanded by Admiral Sir George Rooke (1650-1709). After that battle, he never went to sea again. However, he 'had a real influence on the advancements and selections of officers. ${ }^{40}$ From 1669, the date of the establishment of the Secretary of State for the Navy, to 1777, when two other posts were set up, the Admiral was assisted by two Vice-Admirals of France. ${ }^{41}$ These two general officers were entrusted with the fleet of the Ponant, for the Atlantic Ocean, and the fleet of the Levant, for the Mediterranean Sea. From 1715 to 1774, France had 18 vice-admirals and it is these men who are the subject of this paper.

Some naval officers of the reign of Louis XIV, such as Duquesne, Jean Bart, Duguay-Trouin and Tourville, are famous for their battles or for their

How to cite this book chapter:

Surreaux, S. 2017. The Reputation of Louis XV's Vice-Admirals of France. In: Harding, R and Guimerá, A (eds.). Naval Leadership in the Atlantic World. Pp. 35-47. London: University of Westminster Press. DOI: https://doi.org/10.16997/book2.d. License: CC-BY-NC-ND 4.0 
leadership. The same is true of some officers of the reign of Louis XVI: for example, Suffren, d'Orvilliers, de Grasse, La Pérouse and Kerguelen -Trémarec. However, the historiography of the nineteenth and early twentieth centuries is overwhelmingly negative with regard to most of Louis XV's vice-admirals, or has even forgotten them completely. Their rehabilitation happened only with Michel Vergé-Franceschi's thesis, in 1987, and Étienne Taillemite's Dictionnaire des marins français in 2002. ${ }^{42}$ Professor Vergé-Franceschi demonstrated the importance of family ties in the rise of general officers in La Royale, the French Royal Navy. He researched their careers, chiefly in the 'titles office' of the Bibliothèque Nationale de France. By reading the prosopographical and biographical data in each of these works, two facts became clear. First, with a few exceptions, the reputation of these men is almost unknown. Second, their ability to command and to lead maritime campaigns, and thus their leadership, has not been systematically analysed.

But why should we take an interest in 'reputation', which is a sketchy and rather subjective notion, as a means of examining their leadership? This chapter tries to go beyond the usual studies in leadership, in which the focus is on tactics, strategies or the numbers of opposing forces. Leadership is assessed by such facts, but equally important are the memories of the battles and campaigns evoked: that is, the reputation of the commanders involved. Furetière, in 1690, defined the word 'reputation' as: 'the good opinion the people have of persons, or things', and he went on: 'a captain just needs a victory to have a reputation of courage, and a rout to have ill repute.. ${ }^{43}$ The first edition of the Dictionnaire de l'Académie française, in 1694, described 'reputation' as fame, esteem, in the public opinion. ${ }^{44}$ 'Réputer' derives from Latin 'reputare', which means 'to appraise', and, until the sixteenth century, 'reputatio' meant appraising. Breaking with the verb, the noun acquired the meaning pointed out by Furetière and the French Academy. In 1982, Littré perfected the definition, specifying that reputation is 'the opinion that people have about someone. ${ }^{45}$ During the eighteenth century, the word had a favourable connotation, which differs from Littrés definition, in which people's opinion can be either favourable or critical. To assess a reputation implies an evaluation of the opinions of many protagonists such as the State (the dispenser of favours and promotion), naval officers and seamen (who contributed to their chief's reputation), other contemporaries, and succeeding generations (who absorbed recollections of the vice-admiral, and built these in a body of historical scholarship).

This chapter uses two sources in this search for reputation: the letters patent of provision, or provisions, of the Vice-Admiral of France, and evidence left by contemporaries regarding the ability of these officers to command. The letters patent of provision, which confirmed the appointment of an officer, listed the career of the officer concerned. They give the viewpoint of the State and of the royal institutions about the quality of these men who have been raised 
to the office of vice-admiral. Other contemporary witnesses provide different lights on the subject.

After several months' research in the records from the Archives Nationales' deposits and from the Bibliotheque Nationale, the resultant data is slim. After having scrupulously analysed all the probate inventories of 18 vice-admirals, attempting to find some traces of their deeds in the papers recorded after their deaths, only seven copies of the letters confirming their appointments were located. The historian cannot know exactly where else such documents may have been preserved. There are many likely places. There is some evidence suggesting that these letters were stored in the Great Chancellery. ${ }^{46}$ However, not one has been found in that archive. Either they have been preserved elsewhere or they have vanished. Only one letter patent was found in the series Courts of Accounts of the Parliament of Paris, where it had been reconstituted in the Memorials (series P). ${ }^{47}$ The archives of the French Admiralty were examined, ${ }^{48}$ as well as the personal records of each vice-admiral in the series Marine of the Archives Nationales of France. ${ }^{49}$ Only seven letters of appointment were located, permitting us to see the State's view of the reputation of these vice-admirals. Four of them had been promoted to the rank and dignity of field-marshal, which increased the available sources as it is possible to trace their maritime careers from these letters of appointment as well.

How do these letters of appointment and the remarks of contemporaries help us understand the reputations of the vice-admirals at a time when $L a$ Royale was no longer the force it had been under Louis XIV? The letters patent of provision provide a view of the careers of the new vice-admirals and an important insight into the key factors that made up the reputations of these men.

\section{I - The letters of provision to the Vice-Admiralty of France}

To become a Vice-Admiral of France at a time when there were only two of these posts implies that these men were highly regarded by the monarchy. The appointment was a reward for meritorious service. Thus their leadership or their capacity to command was already recognised in their past success.

Letters of provision give us a clear view of the promotion criteria to the viceadmiralty and to the marshalship. Before they were issued by the War Office or by the Secretary of State of the Navy, the new Vice-Admiral or Marshal of France sent a memorandum regarding his services so that the secretaries could accurately re-transcribe his career into the letters. Most of these surviving letters have been kept as reconstituted copies on parchment or vellum in the registries of the Memorial of the Accounts Chamber, series $\mathrm{P}$, at the Archives 


\begin{tabular}{|c|c|c|c|c|}
\hline \multicolumn{2}{|c|}{ Themes/Expressions } & \multirow{2}{*}{$\begin{array}{c}\text { NB } \\
8\end{array}$} & \multirow{2}{*}{$\begin{array}{c}\text { Names of } \\
\text { vice-admirals }\end{array}$} & \multirow{2}{*}{$\begin{array}{r}\text { Promotions } \\
1703 ; 1730 ; \\
1750 ; 1755 ; \\
1756 ; 1758\end{array}$} \\
\hline A distinction & $\begin{array}{c}\text { Merit, deserve, } \\
\text { 'to adjust rewards } \\
\text { according to merit', } \\
\text { 'a so well-deserved } \\
\text { reward', 'distinguished } \\
\text { merit', 'distinguished } \\
\text { himself,' 'distinguished } \\
\text { himself through } \\
\text { several glorious feats', } \\
\text { 'distinguished services', } \\
\text { 'lot of distinction', } \\
\text { 'served with so much } \\
\text { distinction' }\end{array}$ & & & \\
\hline & $\begin{array}{l}\text { 'Best choice,' in better } \\
\text { hands than his the } \\
\text { command of our } \\
\text { naval armies/our } \\
\text { maritime strength' }\end{array}$ & 5 & $\begin{array}{c}\text { Salaberry de } \\
\text { Benneville; Court de } \\
\text { La Bruyère; Cresnay; } \\
\text { Macnémara; Conflans }\end{array}$ & $\begin{array}{l}1750 ; 1755 ; \\
1756 ; 1758\end{array}$ \\
\hline & 'Reward' & 5 & $\begin{array}{c}\text { d'Estrées, } \\
\text { Château-Renault; } \\
\text { Coëtlogon; Cresnay, } \\
\text { Conflans }\end{array}$ & $\begin{array}{l}1703 ; 1730 \\
1755 ; 1758\end{array}$ \\
\hline \multirow[t]{5}{*}{$\begin{array}{l}\text { Qualities of a } \\
\text { war leader }\end{array}$} & $\begin{array}{c}\text { 'Experienced } \\
\text { in warcraft and } \\
\text { navigation', 'proven } \\
\text { experience in } \\
\text { navigation', 'acquired } \\
\text { experience and } \\
\text { capacity' }\end{array}$ & 5 & $\begin{array}{c}\text { d'Estrées; Salaberry de } \\
\text { Benneville; Court de } \\
\text { La Bruyère; Cresnay; } \\
\text { Macnémara }\end{array}$ & $\begin{array}{l}1684 ; 1750 \\
1755 ; 1756\end{array}$ \\
\hline & $\begin{array}{l}\text { Victories: 'happy } \\
\text { successes' }\end{array}$ & 5 & $\begin{array}{c}\text { Salaberry de } \\
\text { Benneville; Court de } \\
\text { La Bruyère; Cresnay; } \\
\text { Macnémara; Conflans }\end{array}$ & $\begin{array}{l}1750 ; 1755 ; \\
1756 ; 1758\end{array}$ \\
\hline & $\begin{array}{l}\text { 'Fortunate } \\
\text { dispositions' }\end{array}$ & 1 & d'Antin & 1731 \\
\hline & 'Courage' & 2 & $\begin{array}{l}\text { Coëtlogon; Court de } \\
\text { La Bruyère }\end{array}$ & $1730 ; 1750$ \\
\hline & 'Good conduct' & 5 & $\begin{array}{c}\text { Salaberry de } \\
\text { Benneville; Court de } \\
\text { La Bruyère; Cresnay; } \\
\text { Macnémara; Conflans }\end{array}$ & $\begin{array}{l}1750 ; 1755 ; \\
1756 ; 1758\end{array}$ \\
\hline
\end{tabular}




\begin{tabular}{|c|c|c|c|c|}
\hline \multicolumn{2}{|c|}{ Themes/Expressions } & \multirow{2}{*}{$\begin{array}{c}\text { NB } \\
5\end{array}$} & \multirow{2}{*}{$\begin{array}{c}\text { Names of } \\
\text { vice-admirals }\end{array}$} & \multirow{2}{*}{$\begin{array}{l}\text { Promotions } \\
1750 ; 1755 ; \\
1756 ; 1758\end{array}$} \\
\hline & 'Prudence,' 'vigilance' & & & \\
\hline & $\begin{array}{l}\text { 'Reputation he } \\
\text { legitimately gained', } \\
\text { 'so much cleverness' }\end{array}$ & 1 & Court de La Bruyère & 1750 \\
\hline & 'Valour' & 7 & $\begin{array}{c}\text { d'Estrées; } \\
\text { Château-Renault; } \\
\text { Salaberry de } \\
\text { Benneville; Court de } \\
\text { La Bruyère; Cresnay; } \\
\text { Macnémara; Conflans }\end{array}$ & $\begin{array}{l}1684 ; 1703 ; \\
1750 ; 1756 ; \\
1758\end{array}$ \\
\hline & Zeal & 5 & $\begin{array}{c}\text { Château-Renault; } \\
\text { Coëtlogon; Salaberry } \\
\text { de Benneville; Cresnay; } \\
\text { Conflans }\end{array}$ & $\begin{array}{l}1703 ; 1730 ; \\
1750 ; 1755 ; \\
1758\end{array}$ \\
\hline \multirow{4}{*}{$\begin{array}{l}\text { Service to } \\
\text { the King and } \\
\text { King's grate- } \\
\text { fulness }\end{array}$} & Mentioned wounds & 2 & Cresnay; Conflans & $1755 ; 1758$ \\
\hline & $\begin{array}{l}\text { 'Affection to our } \\
\text { service' }\end{array}$ & 5 & $\begin{array}{c}\text { Château-Renault; } \\
\text { Salaberry de } \\
\text { Benneville; Court de } \\
\text { La Bruyère; Cresnay; } \\
\text { Conflans } \\
\end{array}$ & $\begin{array}{l}1703 ; 1750 \\
1755 ; 1758\end{array}$ \\
\hline & $\begin{array}{l}\text { Faithfulness to the } \\
\text { King and to the } \\
\text { Crown }\end{array}$ & 1 & d'Estrées & 1684 \\
\hline & $\begin{array}{l}\text { 'Confidence we } \\
\text { rightly placed in him”, } \\
\text { 'extreme confidence } \\
\text { that we always placed } \\
\text { in him' }\end{array}$ & 2 & $\begin{array}{c}\text { Salaberry de } \\
\text { Benneville; Cresnay }\end{array}$ & $1750 ; 1755$ \\
\hline \multirow{3}{*}{$\begin{array}{c}\text { Social } \\
\text { origins, } \\
\text { tradition } \\
\text { and family } \\
\text { memories }\end{array}$} & $\begin{array}{c}\text { 'Birth', 'advantages of } \\
\text { birth' }\end{array}$ & 5 & $\begin{array}{l}\text { d'Estrées; Château- } \\
\text { Renault; Coëtlogon; } \\
\text { d'Antin; Conflans }\end{array}$ & $\begin{array}{l}1703 ; 1730 \\
1731 ; 1758\end{array}$ \\
\hline & 'Ancestors,' 'ancestor' & 1 & Château-Renault & 1703 \\
\hline & $\begin{array}{l}\text { Reminder of the } \\
\text { character of father or } \\
\text { of a marshal or vice- } \\
\text { admiral's relatives }\end{array}$ & 2 & d'Estrées; d’Antin & $1684 ; 1731$ \\
\hline
\end{tabular}

Fig. 1: Analysis of the reputation of vice-admirals through promotion criteria to vice-admiralty or marshalship in their letters of provision. 
Nationales and in paper form in the individual files of the vice-admirals in the Archives Nationales.

As official acts, they are all written in the same form. ${ }^{50}$ Eight copies of letters of provision to the vice-admiralty and four copies of the letters of provision to vice-admirals appointed as marshals were found..$^{51}$ The standardised nature of the letters might suggest a document that was a matter of form rather than an accurate assessment of an individual officer's career. Nevertheless, searching for terms and expressions, or even connotations and facts not mentioned in other examples, may help distinguish between the more or less consistent promotion criteria. These criteria express the reputation and the leadership abilities of vice-admirals. Figure 1 aims to establish the promotion criteria as they appeared in the letters. These terms or expressions enable us to assess the profile of a 'good' Vice-Admiral of France. Letters of provision include four types of useful information for an historical analysis of the sources of distinction: data related to reward, data related to qualities and skills as war leader, data related to service and commitment to the King, and expressions qualifying the social origins, tradition and family memories of the newly promoted, as though, in the last case, the blood flowing in his veins confirmed the accuracy of the monarch's decision.

\section{Vice-admiralty: A distinction}

Out of a total of 12 letters of provision (vice-admirals and marshals together), eight feature specific terms related to the 'merit' of the character. From the Latin meritum, 'merit' derives from merere and means 'earn', 'get as a prize or a reward'. In common Latin, the word has been associated with the meaning of 'value.' In ancient French, the word had more meanings than are in modern use. Though in the first texts it means 'salary, punishment or reward', modern use was established in the seventeenth century when merit was associated with 'skills, wholly respectable moral and intellectual qualities'. More specifically, it refers to talent, seamanship (1668 'gens de mérite'). ${ }^{52}$ According to Furetière, merit falls within 'the putting together of several virtues or good qualities, in any person, which attracts consideration and admiration on him. ${ }^{53}$ But merit can also be associated with 'the price, the value of actions and things compared with their good or bad content. ${ }^{54}$ Therefore, vice-admiralty is considered in most cases as the prize for the military actions of those promoted. This criterion of distinction seems essential during the reign of Louis XIV.

Reward is found next to merit. Five patent letters claim that the granting of vice-admiralty was not an honour but a reward. 'To reward' means 'recognize the merit of someone through a favour' (Montaigne, 1580) and refers to a fortunate consequence which constitutes a gratification (1671). ${ }^{55}$ Furetière defines the reward as 'the price, the salary, the gift to someone or the advantage he is granted in return of services done or for a good action. ${ }^{56}$ Merit and reward 
therefore seemed intertwined, which imposes the conclusion that only merit should have secured promotions to vice-admiralty.

\section{Qualities of the naval war leader}

The qualities that made up a naval leader, such as being an accomplished seaman and distinguished among other general officers, also came into consideration. Valour (in seven cases) was often accompanied by experience and leadership qualities (five cases). In equal numbers, prudence, good conduct and zeal (five cases) were often added, while courage (two cases) was also considered. The term of zeal, however vague ('ardour, affection, passion in something'), may have referred to the aptitude to command troops and to serve the King faithfully by complying with orders.

Behind the word 'courage' lies a reference to the heart. As a matter of fact, 'courage' features in a very general sense in ancient and middle French. Until the seventeenth century, it particularly defined the strength of soul, moral virtue in any field and, more specifically, the qualities of an elite nature, which were synonymous with 'heart', in a figurative sense. ${ }^{57}$ A courageous vice-admiral was therefore a man different from his fellows because of the nature and strength of his soul. The corollary of these moral virtues is prudence, which is, according to Furetière, 'the first of the cardinal virtues which teaches one to manage one's life and customs and to guide one's actions according to right reasoning. Prudence's main function is to assess what has been done, what has to be done and what must be avoided'. ${ }^{58}$ Courage is intertwined with prudence and also with valour, defined by Furetière as 'a firmness of soul which makes one look on the perils of war with cold blood, that is with fervour for real glory'.59 Then comes zeal, defined as 'ardour, affection, passion in something'. ${ }^{60}$

The case of Dubois de La Motte (1683-1764) epitomises these criteria. He entered the Garde de la Marine in 1698 and was a lieutenant from 1709 to 1727. Sieur Duguay-Trouin (1673-1736) recommended him to the Secretary of State of the Navy, the Comte de Maurepas. Duguay-Trouin wanted to see him promoted to captain, stating: 'this officer is not only able skilfully to command any ship, but also several of them at the same time. This opened the possibility that he might, in future, become a good squadron leader. Duguay-Trouin praised 'his valour', 'his prudence' his 'sang froid in action.' ${ }^{1}$ In 1746-7, Dubois de La Motte commanded the ship Le Magnanime (74) on a voyage to the West Indies and back. He emerged from this campaign with great credit. He then protected a convoy of 40 merchant ships with the frigate L'Etoile. He was chased by four British ships and came under fire from a couple of them. At three oclock the next morning, the British gave up; Dubois had not lost a single ship from his convoy. On 1 August 1747, Maurepas noted for the King's attention that 'M. Dubois de la Motte gave the utmost care for the security of the fleets he led to and from Santo-Domingo, and he distinguished himself in the two fights he waged on this occasion. ${ }^{62}$ The 
Chambers of Commerce were satisfied with Dubois de la Motte's actions. Michel Vergé-Franceschi describes him as an 'excellent, energetic and daring tactician'; 'he reminds us of the privateer under Louis XIV [Duguay-Trouin], his fellow countryman, for whom he was often the appreciated subordinate. ${ }^{63}$

So the four main qualities of the naval leader are courage, prudence, valour and zeal. On the other hand, outstanding courage and seamanship do not seem to have been essential to reach vice-admiralty. Only Claude-Élisée de Court de La Bruyère (1666-1752) was identified as a courageous clever man of good reputation. Aged 78, he led the French squadron in the fight at Cap Sicié (Battle of Toulon) on 22 February 1744. In Le Terrible (74), he commanded a squadron of 13 ships whose objective was to assist a Spanish squadron of 14 ships under Admiral Juan José Navarro (1687-1772) to get out of Toulon Harbour, in the face of a British squadron of 30 ships under Vice-Admiral Thomas Mathews. In the action that followed, the Franco-Spanish squadron succeeded in breaking through the British force and away towards Spain. ${ }^{64}$ Thus it seems from the official notifications that, excluding courage and reputation, the main leadership skills could be summed up by these four words: experience, prudence, valour and zeal.

\section{From King's service to the recognition of family merits}

Battle wounds were the proof of the gift of one's body to the king and to the nation. If a vice-admiral had fought and shed his blood, it was a distinctive criterion in the letters of provision. However, it was not crucial since only two vice-admirals' letters mention their wounds. Nevertheless, mentioning these wounds was significant, especially for Félix de Poilvilain de Cresnay (16931756), vice-admiral for six months before his death, who almost lost a hand at the Battle of Dettingen on 27 June 1743, while he commanded the guards company of the Admiral's boat. ${ }^{65}$

Then come affection (five cases), trust (two cases) and faithfulness (one case) to the King and to the crown. These terms reveal the close link between those promoted and the monarch. Such qualities referred to the personal, almost privileged, relationship between the King and men judged suitable to be granted the power of Vice-Admiral of France, as they were to command warships and troops in the name of the monarch. Finally, there was social origin, tradition and the family history of the vice-admirals. Five individuals promoted to be Vice-Admiral of France are noted for their birth, their ancestors and their families.

To sum up, being promoted to the dignity of Vice-Admiral of France in the course of the eighteenth century was, therefore, considered as a reward for military merit. Each new vice-admiral possessed at least one of the qualities derived from the four main themes considered here. He was distinguished through his own eminent qualities, his dignity, as a deserved reward, and as 
recognition of his family's and his own proven services to the crown. We now turn to how the leadership reputation of these men was assessed, through one case where it was stained by defeat: that of marshal and vice-admiral Hubert de Brienne, Comte de Conflans (1690-1777), whose reputation was to be severely damaged by a single, but devastating, defeat.

\section{II - A tarnished reputation and questioned leadership? Hubert de Conflans and the Battle of Quiberon Bay}

Defeat in naval operations is undoubtedly the worst possible fate for a naval officer and disgrace logically followed from it. However, several vice-admirals were not disgraced despite their failures. During the Seven Years' War (1756-63), Vice-Admiral the Comte d'Aché de Serquigny (1701-80) was sent to India to support the French East India Company forces against the British along the Coromandel Coast. He was criticised for his failure to support an attack upon Madras or to support the defence of Pondicherry, both of which ended in defeat for the French. Nevertheless, with the support of the Secretary of State for the Navy, Nicolas Berryer, Comte de La Ferrière, he escaped prosecution, leaving his reputation and leadership untarnished - unlike the army commander at Pondicherry, Lally-Tollendal, who was executed for the disgrace in $1766 .{ }^{66}$

By comparison with Marshals of France, few naval officers were recalled after a failure. Although not a marshal at the time, the Prince de Soubise (1715-87) kept his position after the disastrous Battle of Rossbach on 5 November 1757, as did the Marquis de Contades (1704-95) after his defeat at the Battle of Minden on 1 August 1759. ${ }^{67}$ However, François Duc de Villeroy (1644-1730) and Louis La Feuillade (1673-1724) both lost their military careers during the War of the Spanish Succession, although Villeroy went on to occupy a high position of state under the Regency. La Feuillade never served again after his defeat at Turin in 1706. Similarly, the Comte de Broglie (1671-1745) suffered military and political disgrace after his defeat in Bavaria in 1741. Both La Feuillade and de Broglie were exiled despite the fact that they had done nothing particularly blameworthy in leading their armies in very difficult circumstances. In the navy, only Conflans was recalled and never employed again at sea after his defeat at the Battle of Quiberon Bay (21 November 1759).

\section{i. Conflans: A skilful general officer in a forsaken navy}

Hubert de Conflans was described in the corps as a 'good officer, skilful at doing his job, brave but slightly quick-tempered and excessively proud of his birth; pretends to descend from the Kings of Jerusalem.68 He joined the Gardes 
Marine in 1706, was sub-lieutenant in 1712, ship lieutenant in 1727 and commander of the company of the Gardes Marine in Brest from 1741 to 1746 . He was kept busy with the concerns of the Chambers of Commerce of Nantes and La Rochelle, and with the poor coastguards in Brest. 'Humane, ready to teach and clever, Conflans tried, to the extent of his resources, to improve the quality of the navy' ${ }^{69}$ As a war leader, commanding the ship Le Content (62) from 1740 onwards, he seized the Northumberland (70) in 1744 . In 1746 he commanded Le Terrible (74) and safely escorted a convoy of 90 ships between Santo Domingo and Europe. On 29 October 1746 he met a British force and seized the Severn (50). On Christmas Day 1746, Maurepas, then Secretary of State for the Navy, presented to the King an account of the conduct of Conflans in his different assignments:

'He carried out his task with as much conduct as valour. He led and brought back to safe harbour numerous fleets which provided great wealth within the State. He successfully waged several campaigns.' ${ }^{70}$

In 1752, he was the eldest lieutenant general in the navy. At the top of his military career, as Vice-Admiral of Ponant in March 1756, Conflans proved a skilful general officer and he was deemed the best to fight the Royal Navy. He was therefore granted his marshal's baton in March 1758, much to Vice-Admiral Barrailh's displeasure. ${ }^{71}$ For the first time in 55 years, a vice-admiral was promoted to the position of marshal. (The previous cases had been d'Estrées and Château-Renault in 1703.) The title was aimed at providing Conflans with additional authority. He was to 'command the Brest fleet, made up of 28 line ships, the smallest of which still features 64 cannons, and are considered as magnificent ships. ${ }^{72}$ Luynes noted:

'He is an officer of great reputation in the navy [...]. It was fair that the King gave the navy a Marshal of France, as there had not been any since the late Marshal d'Estrées. Such a well-composed corps, which has distinguished itself for a long time, is more than ever necessary in the present circumstances. ${ }^{73}$

He was assigned the difficult task of preparing the ships in order to invade England at a time when the French navy was not functioning well.

\section{ii. The Battle of Quiberon Bay: A failure of leadership?}

Conflans understood the importance of the navy. On 27 September 1757, he wrote to the Duke of Aiguillon, commander-in-chief in Brittany: 'the interest of the navy shall not be overlooked for a single moment, otherwise the fate 
and the advantages of the Kingdom might be at stake. ${ }^{74}$ This statement alone should, according to Vergé-Franceschi, 'rehabilitate this general officer accused of incapacity after the Cardinals disaster. ${ }^{35}$

In 1759 Conflans flew his flag in the Soleil-Royal (80). His squadron was 'in poor conditions, hastily armed with dilapidated artillery. The crew was made up of landsmen who were at sea for the first time, lacking elementary training, which may account for many wrong moves. ${ }^{76}$ A total of 21 ships left Brest on 14 November 1759 to embark troops in the area of Vannes in southern Brittany. Conflans tried to avoid a battle but was caught by Admiral Sir Edward Hawke with his 32 ships on 21 November, near the Bay of Quiberon, in the area of Belle-Île-en-Mer. He performed 'skilful manoeuvres but, badly seconded by some of his subordinates, he was unable to prevent his squadron scattering during a violent storm. ${ }^{77}$ Hawke took advantage of the disorganised flight and Conflans lost five ships. Two were seized, three were wrecked and seven took refuge in the Vilaine until early January 1760.

The loss of Quebec in September 1759, and - in practice - of Canada, the defeat at Minden in August and this failure contributed to make the year 1759 an 'annus horribilis'. The way Conflans's fleet was defeated worsened the impact of this defeat. Conflans ran his flagship, the Soleil-Royal, aground and it was burnt near Croisic. Some 2,500 French seamen perished while 300 to 400 English seamen were killed. ${ }^{78}$ Hawke lost two line ships and one was seized, but the French navy could no longer face the Royal Navy in battle. ${ }^{79}$

Conflans was not long in coming to Court to justify himself. Barbier wrote that in December 1759, 'the Marquess ${ }^{80}$ of Conflans came recently to Versailles to clear himself of the defeat and to accuse the Marquess of Beauffremont'. ${ }^{81} \mathrm{He}$ reproached Versailles for having assigned him an impossible task. He accused his ship commanders. He quarrelled with Beauffremont, one of his subordinates in the Bay of Quiberon, thus continuing to bring discredit upon the navy after the rout. While he received no official blame, Conflans was no longer welcome at Versailles. Lord Anson's brother-in-law wrote about him that 'for his behaviour, Mr de Conflans would deserve his marshal's baton to be broken on his shoulders. ${ }^{82}$

In 1760, no squadron was equipped. Small divisions of ships were sent out to perform specific missions designed to divert attention, to counterbalance the defeat on the sea and to inspire troops with a renewed confidence. A few days after Conflans's journey to Versailles, on 20 December 1759, the King appointed Victor François, Comte de Broglie (1718-1804) as a Marshal of France. ${ }^{83}$ Conflans never served on the sea again. Even if, at the end of the day, this defeat contributed to the restoration of the navy by Choiseul and Castries, no naval officer was ever again appointed to the position of Marshal of France. Conflans retired to his estates and was forgotten until he died in Paris in January 1777, in accommodation he rented on Rue Saint Dominique. The Bay of Quiberon 


\begin{tabular}{|c|c|c|c|c|c|}
\hline \multicolumn{3}{|c|}{ Levantine Vice-Admiralty, created 1669} & \multicolumn{3}{|c|}{ Ponantine Vice-Admiralty, created 1669} \\
\hline $\begin{array}{c}\text { Name } \\
\text { (birth-death) }\end{array}$ & $\begin{array}{l}\text { Time in } \\
\text { charge }\end{array}$ & $\begin{array}{l}\text { Dura- } \\
\text { tion }\end{array}$ & $\begin{array}{c}\text { Name } \\
\text { (birth-death) }\end{array}$ & $\begin{array}{l}\text { Time in } \\
\text { charge }\end{array}$ & $\begin{array}{l}\text { Dura- } \\
\text { tion }\end{array}$ \\
\hline $\begin{array}{c}\text { François Louis } \\
\text { Rousselet } \\
\text { de Château-Renault } \\
(1637-1716)\end{array}$ & $\begin{array}{c}1 \text { June } \\
1701-15 \\
\text { November } \\
1716\end{array}$ & $\begin{array}{l}15 \text { years } \\
\text { and } \\
5 \text { months }\end{array}$ & \multirow[t]{2}{*}{$\begin{array}{l}\text { Victor-Marie } \\
\text { d'Estrées } \\
(1660-1737)\end{array}$} & & \multirow[t]{2}{*}{$\begin{array}{l}30 \text { years } \\
\text { and } \\
7 \text { months }\end{array}$} \\
\hline $\begin{array}{l}\text { Alain Emmanuel } \\
\text { de Coëtlogon } \\
(1646-1730)\end{array}$ & $\begin{array}{c}18 \\
\text { November } \\
1716-7 \text { June } \\
1730\end{array}$ & $\begin{array}{l}13 \text { years } \\
\text { and } \\
7 \text { months }\end{array}$ & & & \\
\hline $\begin{array}{l}\text { Charles, Earl of } \\
\text { Sainte Maure } \\
(1655-1744)\end{array}$ & $\begin{array}{c}8 \text { June } \\
1730-23 \\
\text { September } \\
1744\end{array}$ & $\begin{array}{l}14 \text { years } \\
\text { and } \\
3 \text { months }\end{array}$ & $\begin{array}{c}\text { Antoine } \\
\text { François de } \\
\text { Pardaillan de } \\
\text { Gondrin, mar- } \\
\text { quess of Antin } \\
(1709-1741)\end{array}$ & $\begin{array}{c}28 \\
\text { December } \\
1737-24 \\
\text { April } 1741\end{array}$ & $\begin{array}{l}3 \text { years } \\
\text { and } \\
4 \text { months }\end{array}$ \\
\hline $\begin{array}{l}\text { Gaspard de Goussé } \\
\text { de La Roche-Allart } \\
\quad(1664-1745)\end{array}$ & $\begin{array}{c}1-7 \\
\text { January } 1745\end{array}$ & 6 days & $\begin{array}{l}\text { François de } \\
\text { Briqueville, } \\
\text { marquess of } \\
\text { La Luzerne } \\
(1665-1746)\end{array}$ & $\begin{array}{c}1 \text { May } \\
1741-29 \\
\text { September } \\
1746\end{array}$ & $\begin{array}{l}5 \text { years } \\
\text { and } \\
4 \text { months }\end{array}$ \\
\hline \multicolumn{6}{|c|}{ Vacancy between 1746 and 1750} \\
\hline $\begin{array}{l}\text { Vincent de } \\
\text { Salaberry } \\
\text { de Benneville } \\
(1663-1750)\end{array}$ & $\begin{array}{c}7 \text { February } \\
1750-30 \\
\text { December } \\
1750\end{array}$ & $\begin{array}{c}10 \\
\text { months }\end{array}$ & $\begin{array}{l}\text { Claude Élisée } \\
\text { de La Bruyère } \\
\text { de Court } \\
(1666-1752)\end{array}$ & $\begin{array}{c}7 \text { February } \\
\text { 1750-19 } \\
\text { August } 1752\end{array}$ & $\begin{array}{l}2 \text { years } \\
\text { and } \\
6 \text { months }\end{array}$ \\
\hline $\begin{array}{l}\text { Pierre de Blouet, } \\
\text { Knight of Camilly } \\
\quad(1666-1753)\end{array}$ & $\begin{array}{c}17 \text { May } \\
1751-22 \text { July } \\
1753\end{array}$ & $\begin{array}{l}2 \text { years } \\
\text { and } \\
2 \text { months }\end{array}$ & $\begin{array}{c}\text { François Cornil } \\
\text { Bart } \\
(1677-1755)\end{array}$ & $\begin{array}{c}1 \text { September } \\
1752-24 \\
\text { April } 1755\end{array}$ & $\begin{array}{c}2 \text { years } \\
\text { and } \\
7 \text { months }\end{array}$ \\
\hline $\begin{array}{l}\text { Jean André de Bar- } \\
\text { railh (1671-1762) }\end{array}$ & $\begin{array}{c}25 \text { August } \\
1753-25 \\
\text { August } 1762\end{array}$ & 9 years & $\begin{array}{c}\text { Félix de } \\
\text { Poilvilain } \\
\text { de Cresnay } \\
(1693-1756)\end{array}$ & $\begin{array}{c}25 \\
\text { September } \\
1755-20 \\
\text { May } 1756\end{array}$ & 8 months \\
\hline $\begin{array}{c}\text { Emmanuel Auguste } \\
\text { de Cahideuc, Earl } \\
\text { Dubois de la Motte } \\
\quad(1683-1764)\end{array}$ & $\begin{array}{c}13 \text { October } \\
1762-23 \\
\text { October } \\
1764\end{array}$ & 2 years & $\begin{array}{l}\text { Jean-Baptiste } \\
\text { Macnémarra } \\
(1690-1756)\end{array}$ & $\begin{array}{c}17-18 \\
\text { October } \\
1756\end{array}$ & 1 day \\
\hline $\begin{array}{c}\text { Claude Louis, Mar- } \\
\text { quess of Massiac } \\
(1686-1770)\end{array}$ & $\begin{array}{l}4 \text { November } \\
1764-15 \\
\text { August } 1770\end{array}$ & $\begin{array}{l}5 \text { years } \\
\text { and } \\
9 \text { months }\end{array}$ & $\begin{array}{c}\text { Hubert de } \\
\text { Brienne, Earl } \\
\text { of Conflans } \\
(1690-1777)\end{array}$ & $\begin{array}{c}14 \\
\text { November } \\
1756-27 \\
\text { January } 1777 \\
\end{array}$ & $\begin{array}{l}20 \text { years } \\
\text { and } \\
2 \text { months }\end{array}$ \\
\hline $\begin{array}{l}\text { Anne Antoine, } \\
\text { Earl of Aché } \\
\text { de Serquigny } \\
(1702-1780)\end{array}$ & $\begin{array}{l}24 \text { August } \\
1770-11 \\
\text { February } \\
1780\end{array}$ & $\begin{array}{l}9 \text { years } \\
\text { and } \\
5 \text { months }\end{array}$ & & & \\
\hline
\end{tabular}

Fig. 2: Louis XV's vice-admirals (1715-74). 
defeat, his behaviour and the overall circumstances of the kingdom in 1759-60 put an end to his career. This man, after having reached the highest military position in a couple of years (1756-8), saw his social status and his reputation destroyed by a single defeat.

Conflans was the only Marshal of France to have experienced such an end. ${ }^{84}$ Military incompetence was a necessary but insufficient criterion to explain his disgrace, since no rule seems to have existed in this matter. Thus, according to Vergé-Franceschi, Conflans might be considered to have been 'a very severely judged officer. ${ }^{85}$

\section{Conclusion}

If the French navy during the reign of Louis XV was weaker than under Louis XIV and Seignelay or Louis XVI and Castries, the general officers who commanded this navy were nevertheless skilful men. They deserved their titles of vice-admirals even if they did owe it in part to a seniority rule and they were often appointed late in their lives. The recognition of their leadership by the King in their letters of provision was based on recurring qualities: experience, valour, zeal and prudence. During this period, a good naval officer was a prudent seaman who was anxious to preserve his ship and his men at a time when only a small budget was allocated to the navy ${ }^{86}$ The Seven Years' War and the defeat at the Battle of Quiberon Bay resulted in important changes in attitudes which, from then on, saw the quality of training for seamen and officers rising significantly. 
